\title{
GURU DAN MOTIVASI BELAJAR AGAMA ANAK TUNA GRAHITA
}

\section{Etik Kurniawati}

Sekolah Tinggi Ilmu Tarbiyah (STIT) Madina Sragen

etik_k@ymail.com

Religious Education given to children with intellectual challenges are different from normal children in general. The difference is not in its subject matter, but in terms of the extent and development of materials of religious education tailored to the child's ability. A Mentally dissabled child is not easy to be educated about the teaching of religion, because the limitations in capturing the religious instruction and behavior different from normal children. Teachers have an important character such as a motivator. Teachers should be able to increase or stimulate activity, provide encouragement, as a good example, as well as providing facilities for students to have a passion in studying religion, especially in the process of learning in children with intellectual challenges who have mental conditions that are different from normal children. Therefore, it is important for teachers to give encouragement or stimulus that they have a passion and interest in the study of religion.

Keywords: Teacher, Motivation, Mentally disabled 


\section{A. Pendahuluan}

Salah satu faktor yang paling menentukan dalam proses pembelajaran di kelas adalah guru. Tugas guru yang paling utama adalah mengajar dan mendidik. Sebagai pengajar guru merupakan peranan aktif (medium) antara peserta didik dengan ilmu pengetahuan Mendidik itu sebagian dilakukan dalam bentuk mengajar, sebagian dalam bentuk memberikan dorongan, memuji, menghukum, memberi contoh, membiasakan, dan lain-lain.

Guru mempunyai peranan sebagai komunikator, sahabat yang dapat memberikan nasehatnasehat, motivator sebagai pemberi inspirasi dan dorongan pembimbing dalam pengembangan sikap dan tingkah laku serta nilai-nilai orang yang menguasai bahan yang diajarkan. ${ }^{1}$

Secara umum dapat dikatakan bahwa tugas dan tanggungjawab yang harus dilaksanakan oleh guru adalah mengajak orang lain berbuat baik. Tugas tersebut identik dengan dakwah islamiyah yang bertujuan mengajak umat Islam untuk berbuat baik. Di dalam Al-Qur'an Ali Imran ayat 104 Allah berfirman:

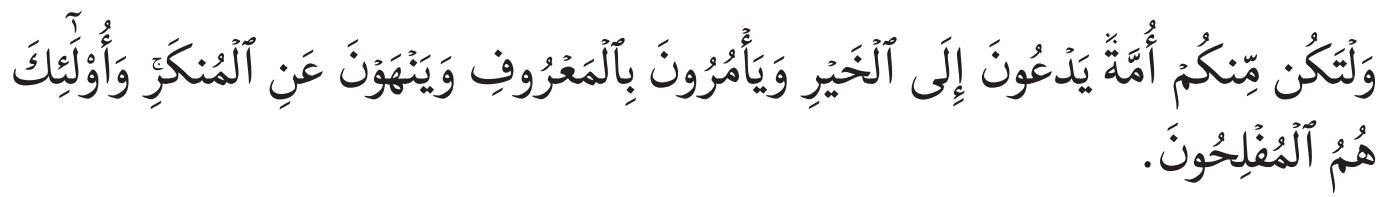

Artinya: "Dan hendaklah di antara kamu segolongan umat yang menyeru kepada kebaikan, menyeru kepada yang ma'ruf dan mencegah dari yang mungkar, mereka itulah orang-orang yang beruntung.

Peranan guru sebagai motivator ini penting artinya dalam rangka meningkatkan kegairahan dan pengembangan kegiatan belajar siswa. ${ }^{2}$ Khususnya dalam memotivasi belajar agama agar siswa menjadi manusia yang mempunyai kepribadian muslim, beriman dan bertakwa kepada Allah SWT, berakhlak mulia serta dapat meningkatkan potensi moral dan spiritual yang ada dalam diri siswa. Dalam hal ini adalah peserta didik yang kecerdasannya berada di bawah ratarata yaitu anak tunagrahita.

Mendapatkan pendidikan merupakan hak dan kewajiban setiap warga negara Indonesia tidak terkecuali anak-anak tunagrahita. Anak tunagrahita dikenal juga dengan istilah terbelakang mental karena keterbatasan kecerdasannya mengakibatkan dirinya sukar untuk mengikuti program pendidikan di sekolah biasa secara klasikal. Oleh karena itu anak terbelakang mental membutuhkan layanan pendidikan secara khusus yakni disesuaikan dengan kemampuan anak tersebut. $^{3}$

Kemampuan yang dimiliki antara anak normal dengan anak tunagrahita itu berbeda-beda. Oleh karena rendahnya intelektual dan keterbelakangan mental yang dimiliki anak tunagrahita tersebut sehingga mereka memerlukan adanya motivasi dari seorang guru dalam belajar agama. Motivasi memiliki posisi penentu bagi kegiatan hidup manusia dalam usaha mencapai cita-cita, tanpa motivasi proses belajar tidak akan berjalan dengan baik.

1 Sardiman A.M, Interaksi dan Motivasi Belajar Mengajar (Jakarta: Raja Grafindo Persada, 2002), hlm. 141

2 Sardiman A.M, Interaksi dan Motivasi Belajar Mengajar (Jakarta: Raja Grafindo Persada, 2002), hlm. 143

3 Sitjihati Somantri, Psikologi Anak Luar Biasa, (Bandung: Refika Aditama, 2006), hlm. 103 
Motivasi belajar, dalam hal ini adalah belajar agama merupakan faktor psikis yang bersifat non intelektual. Peranannya yang khas adalah dalam hal penumbuhan gairah, merasa senang dan semangat untuk belajar, khususnya belajar agama. ${ }^{4}$ Dengan demikian motivasi belajar agama memegang peranan penting dalam memberikan semangat belajar sehingga siswa akan memacu motivasi dan energinya untuk belajar agama, sebab terkadang suatu proses belajar mengajar tidak dapat mencapai hasil yang maksimal oleh karena ketidakkuatan daya pendorong atau motivator.

\section{B. Pembahasan}

\section{Guru}

a. Pengertian Guru dalam Pendidikan Islam

Pendidik dalam Islam adalah siapa saja yang bertanggung jawab terhadap perkembangan anak didik. Dalam Islam, orang yang paling bertanggung jawab adalah orang tua (ayah dan ibu) anak didik. Tanggung jawab itu disebabkan oleh dua hal yaitu karena kodrat, yaitu karena orang tua ditakdirkan menjadi orang tua anaknya, oleh sebab itu ia ditakdirkan pula bertanggung jawab mendidik anaknya. Serta, karena kepentingan kedua orang tua yaitu orang tua berkepentingan terhadap kemajuan perkembangan anaknya. ${ }^{5}$

Pendidik dalam Islam adalah guru. Kata guru dalam bahasa Indonesia yang berarti orang yang mengajar. Dalam bahasa inggris dijumpai kata teacher yang berarti pengajar. Dalam bahasa Arab istilah yang mengacu kepada pengertian guru yaitu al-alim (jamaknya ulama) atau almu'allim, yang berarti orang yang banyak mengetahui dan banyak digunakan para ulama/ahli pendidikan. Secara umum guru merupakan orang yang tugas dan pekerjaannya mengajar, ia juga bertugas mendidik dalam rangka pembentukan pribadi anak didiknya. ${ }^{6}$

Guru adalah salah satu komponen manusiawi dalam proses belajar mengajar dan ikut berperan dalam usaha pembentukan sumber daya manusia yang potensial di bidang pembangunan. ${ }^{7}$

Guru dalam pandangan masyarakat adalah orang yang melaksanakan pendidikan di tempat-tempat tertentu, tidak mesti di lembaga pendidikan formal, tetapi bisa juga di masjid, di surau atau musholla, di rumah dan sebagainya. ${ }^{8}$

Dari pengertian-pengertian guru di atas dapat disimpulkan bahwa guru adalah orang yang mempunyai tugas mengajar orang lain secara individu maupun kelompok atau klasikal pada lembaga pendidikan formal maupun non formal.

b. Tugas Guru dalam Islam

Dalam prespektif humanisme religious, guru tidak dibenarkan memandang anak didik

4 Sardiman A.M, Interaksi dan Motivasi Belajar Mengajar, (Jakarta: Raja Grafindo Persada, 2001), hlm. 73

5 Ahmad Tafsir, Ilmu Pendidikan dalam Pespektif Islam, (Bandung: Remaja Rosdakarya, 1994), hlm. 74

6 Dr. H. Abuddin Nata, M.A. Perspektif Islam tentang Pola Hubungan Guru-Murid (Jakarta :Raja Grafindo Persada, 2001), hlm. 41

7 Sardiman A.M, Interaksi dan Motivasi Belajar Mengajar, (Jakarta: Raja Grafindo Persada, 1996), hlm. 123

8 Syaiful Bahri Djamarah, Guru dan Anak Didik dalam Interaksi Edukatif, (Jakarta: Rineka Cipta, 2000), hlm. 31 
dengan mata sebelah, tidak sepenuh hati, atau bahkan memandang rendah kemampuan siswa. ${ }^{9}$ Ahli-ahli pendidikan Islam juga ahli-ahli pendidikan Barat telah sepakat bahwa tugas guru ialah mendidik. Mendidik adalah tugas yang sangat luas. Mendidik itu sebagian dilakukan dalam bentuk mengajar, sebagian dalam bentuk memberikan dorongan, memuji, menghukum, memberi contoh, membiasakan, dan lain-lain. ${ }^{10}$

Ada tiga tugas pokok profesi guru yaitu guru sebagai pengajar, guru sebagai pembimbing dan guru sebagai administrator kelas. ${ }^{11}$

1) Guru sebagai pengajar lebih menekankan kepada tugas dalam merencanakan dan melaksanakan pengajaran. Dalam tugas ini guru dituntut memiliki seperangkat pengetahuan dan keterampilan teknis mengajar, di samping menguasai ilmu dan bahan yang akan diajarkan.

2) Guru sebagai pembimbing memberi tekanan kepada tugas, memberikan bantuan kepada siswa dalam pemecahan masalah yang dihadapinya.

3) Guru sebagai administrator kelas pada hakikatnya merupakan jalinan antara ketatalaksanaan pada umumnya.

Selain tugas-tugas di atas, guru di sekolah juga harus dapat menjadikan dirinya sebagai orang tua kedua. Ia harus mampu menarik simpati sehingga menjadi idola para siswanya. Pelajaran agama yang disampaikannya, hendaknya dapat menjadikan motivasi bagi siswanya dalam belajar agama.

c. Syarat Guru dalam Pendidikan Islam

Mendidik siswa di sekolah luar biasa tidak sama dengan mendidik siswa di sekolah umum. Yang perlu dipahami oleh pendidik yang memiliki siswa tunagrahita adalah guru harus memahami anak didik yang memiliki keunikan tersendiri yaitu bersifat pelupa, susah memahami perintah yang kompleks, perhatian mudah terganggu, dan susah memahami hal-hal yang kompleks. Oleh karena itu guru siswa tunagrahita harus memiliki syarat-syarat tertentu.

Syarat terpenting bagi guru dalam Islam adalah sebagai berikut: ${ }^{12}$

1) Umur, harus sudah dewasa

Tugas mendidik adalah tugas yang amat penting karena menyangkut perkembangan seseorang. Oleh karena itu harus dilakukan secara bertanggung jawab. Itu hanya dilakukan oleh orang yang sudah dewasa.

2) Kesehatan, harus sehat jasmani dan rohani

Jasmani yang tidak sehat akan menghambat pelaksanaan pendidikan, bahkan dapat membahayakan anak didik apabila mempunyai penyakit yang menular. Dari segi rohani, orang gila berbahaya dalam mendidik dan tidak bias bertanggung jawab.

9 Abdurrahman Mas'ud, M.A., Ph.D., Mengagas Format Pendidikan Nondikotomik, (Yogyakarta: Gama Media, 2007), hlm. 194

10 Abdurrahman Mas'ud, M.A., Ph.D., Mengagas Format Pendidikan Nondikotomik, (Yogyakarta: Gama Media, 2007), hlm. 78

11 Nana Sudjana, Dasar-dasar Proses Belajar Mengajar, (Bandung: Sinar Bumi, 1987), hlm. 15

12 Ahmad Tafsir, 2004, Ilmu Pendidikan Dalam Perspektif Islam, (Bandung: Remaja Rosdakarya, 2004), hlm. $63-65$ 
3) Keahlian, harus menguasai bidang yang diajarkannya dan menguasai ilmu mendidik (termasuk ilmu mengajar)

Ini penting sekali bagi pendidik, termasuk guru. Orang tua dirumah sebenarnya perlu sekali mempelajari teori-teori ilmu pendidikan. Dengan pengetahuannya diharapkan ia akan lebih berkemampuan menyelenggarakan pendidikan bagi anak-anaknya dirumah.

4) Harus berkepribadian muslim, berkesusilaan dan berdedikasi tinggi

Syarat ini amat penting dimiliki untuk melaksanakan tugas-tugas mendidik selain mengajar. Dedikasi tinggi tidak hanya diperlukan dalam meningkatkan mutu mengajar. Selain itu juga harus berkepribadian muslim.

Berdasarkan uraian tersebut maka dapat dipahami bahwa untuk menjadi guru syarat yang harus dimiliki adalah ada tidaknya syarat yang bersifat formal (pengetahuan dan keterampilan mengajar) saja tetapi juga kondisi dari dalam dan luar pribadi seperti sehat jasmani dan rohani (psikis, fisik, religiusitas dan moralitas).

d. Peran Guru

Peran guru menurut beberapa pendapat menggambarkan peranan guru sebagai komunikator, sahabat yang dapat memberikan nasihat-nasihat, motivator sebagai pemberi inspirasi dan dorongan, pembimbing dalam mengembangkan sikap dan dorongan, pembimbing dalam mengembangkan sikap dan tingkah laku serta nilai-nilai, orang yang menguasai bahan yang akan diajarkan. ${ }^{13}$

Peranan guru adalah serangkaian tingkah laku yang saling berkaitan yang dilakukan dalam situasi yang saling berkaitan yang dilakukan dalam situasi tertentu serta berkembang dengan kemajuan dan perkembangan siswa yang menjadi tujuannya. Dari pengertian di atas seorang guru sebagai tenaga profesional dituntut untuk selalu berperan aktif dan menerapkan kedudukannya sesuai dengan tugasnya. ${ }^{14}$

2. Motivasi Belajar Agama

a. Motivasi Belajar Agama

1) Pengertian Motivasi Belajar Agama

Kata "motif" diartikan sebagai daya upaya yang mendorong seseorang untuk melakukan sesuatu. Berawal dari kata "motif" itu, maka motivasi dapat diartikan sebagai daya penggerak yang telah menjadi aktif. ${ }^{15}$ Dalam kegiatan belajar, maka motivasi dapat dikatakan sebagai keseluruhan daya penggerak di dalam diri siswa yang menimbulkan kegiatan belajar, yang menjamin kelangsungan dari kegiatan belajar. ${ }^{16}$

Motivasi belajar merupakan faktor psikis yang bersifat non intelektual. Peranannya yang khas adalah dalam hal penumbuhan gairah, merasa senang dan semangat untuk belajar. Motivasi belajar adalah keseluruhan daya penggerak psikis di dalam diri siswa yang menumbuhkan

13 Sardiman A.M, Interaksi dan Motivasi Belajar Mengajar, (Jakarta: Raja Grafindo Persada, 2000), hlm. 141 14 Moh. Uzer Usman, Menjadi Guru Profesional, Bandung: Remaja Rosdakarya, 1998), hlm. 4 
kegiatan belajar, menjamin kelangsungan kegiatan belajar dan memberikan arah kepada kegiatan untuk mencapai tujuan belajar. ${ }^{17}$

Dengan demikian, motivasi belajar memegang peranan penting dalam memberikan semangat belajar sehingga siswa akan memacu motivasi dan energinya untuk belajar, dalam hal ini khususnya yaitu belajar agama.

2) Fungsi motivasi belajar agama

Tanpa adanya motivasi (dorongan) usaha seseorang tidak akan mencapai hasil yang baik, begitu juga sebaliknya. Demikian juga dalam hal belajar agama, belajar agama akan lebih baik jika selalu disertai dengan motivasi yang sungguh-sungguh, dengan mengharap keridhoan Allah SWT, sehingga akan mencapai hasil yang maksimal.

Dalam proses belajar mengajar, motivasi mempunyai peran dan fungsi yang sangat penting. Di antara fungsi motivasi belajar agama adalah: ${ }^{18}$

a) Mendorong manusia untuk bertindak atau berbuat, jadi berfungsi sebagai penggerak atau sebagai motor yang memberikan energi atau kekuatan kepada seseorang untuk melakukan suatu tugas.

b) Menentukan arah perbuatan, yakni ke arah perbuatan suatu tujuan dan cita-cita.

c) Menyeleksi perbuatan, menentukan perbuatan mana yang harus dilakukan, yang sesuai guna mencapai tujuan.

Berdasarkan uraian tersebut di atas maka dapat diketahui bahwa fungsi motivasi dalam belajar itu di samping memberikan dan menggugat minat dan semangat dalam belajar siswa, juga akan membantu siswa untuk memilih jalan atau tingkah laku yang mendukung pencapaian tujuan belajar maupun tujuan hidupnya.

\section{1) Upaya meningkatkan motivasi belajar agama}

Ada empat fungsi guru sebagai pengajar yang berhubungan dengan cara pemeliharaan dan peningkatan motivasi belajar anak didik antara lain: ${ }^{19}$

a) Menggairahkan anak didik

Dalam kegiatan pembelajaran guru harus berusaha menghindari hal-hal yang monoton dan membosankan. Guru harus selalu memberikan kepada anak didik cukup banyak hal-hal yang perlu dipikirkan dan dilakukan.

b) Memberikan harapan realitas

Guru harus memelihara harapan-harapan anak didik yang realitas dan memodifikasi harapan-harapan yang kurang atau tidak realitas. Bila anak telah banyak mengalami kegagalan untuk guru harus memberikan sebanyak mungkin keberhasilan kepada anak didik.

c) Memberikan insentif

17 Winkel, 1987, Psikologi Pengajaran, (Jakarta: Grasindo, 1987), hlm. 92

18 Ngalim Purwanto, Psikologi Pendidikan, (Bandung: Remaja Rosdakarya, 1995), hlm. 70-71

19 Syaiful Bahri Djamarah, Psikologi Belajar, (Jakarta: Rineka Cipta, 2002), hlm. 135 
Adanya karakteristik tujuan menyebabkan seseorang bertingkah laku untuk mencapai tujuan tersebut. Tujuan yang menyebabkan seseorang bertingkah laku tersebut disebut insentif. Insentif dalam pembelajaran agama tidak selalu berupa materi, tetapi bisa berupa nilai atau penghargaan sesuai kadar kemampuan yang dapat dicapai siswa. ${ }^{20}$

d) Mengarahkan perilaku anak didik

Mengarahkan perilaku anak didik adalah tugas guru dituntut untuk memberikan respon terhadap anak didik yang tak terlibat langsung dalam perilaku anak didik adalah dengan memberikan penugasan, bergerak mendekati dengan sikap lemah lembut dan dengan perkataan yang ramah dan baik. ${ }^{21}$

\section{Anak Tunagrahita}

a. Pengertian Anak Tunagrahita

Anak tunagrahita adalah anak yang mempunyai kemampuan intelektual dibawah ratarata. Dalam bahasa asing digunakan istilah-istilah mental retardation, mentally retarded, mental deficiency, mental defective dan lain-lain. Anak tunagrahita memiliki keterbatasan intelegensi, terutama yang bersifat abstrak seperti belajar dan berhitung, menulis dan membaca. Kemampuan belajarnya cenderung tanpa pengertian atau cenderung belajar dengan membeo. ${ }^{22}$

Di samping memiliki keterbatasan intelegensi, anak tunagrahita juga memiliki kesulitan mengurus diri sendiri dalam masyarakat. Selain itu, juga memiliki keterbatasan dalam penguasaan bahasa. Mereka bukannya mengalami kerusakan dalam artikulasi, akan pusat pengolahan (perbendaharaan kata) yang kurang berfungsi sebagai mana mestinya. Keterbatasan lain yang dimiliki oleh anak tunagrahita yaitu kurang mampu untuk mempertimbangkan sesuatu, membedakan antara yang baik dan buruk, dan membedakan yang benar dan salah. Ini semua karena kemampuannya terbatas, sehingga anak tunagrahita tidak dapat membayangkan terlebih dahulu konsekuensi dari suatu perbuatan. ${ }^{23}$ Oleh karena itu anak tunagrahita memerlukan penanganan khusus termasuk dalam bidang pendidikan agama karena mereka memiliki kesulitan dalam tugas akademik, komunikasi maupun sosial.

b. Klasifikasi Anak Tunagrahita

Klasifikasi anak tunagrahita pada umumnya didasarkan pada taraf intelegensinya, yaitu sebagai berikut: ${ }^{24}$

1) Tunagrahita Ringan (debil atau maron)

Tunagrahita ringan adalah anak tunagrahita yang memiliki IQ 50-75, mereka mampu dididik tetapi tidak mampu mengikuti pendidikan pada program sekolah biasa.

Dengan bimbingan dan pendidikan yang baik tunagrahita ringan pada saatnya akan memperoleh penghasilan untuk dirinya sendiri dan dapat hidup mandiri.

20 Muhaimin, Paradigma Pendidikan Islam (Upaya Mengefektifkan Pendidikan Agama Islam di Sekolah), Bandung: Remaja Rosdakarya, 2002), hlm. 139

21 Syaiful Bahri Djamarah, Psikologi Belajar, (Jakarta: Rineka Cipta, 2002), hlm.136

22 Sutjihati Somantri, Psikologi Anak Luar Biasa, (Bandung: PT. Refika Aditama, 2006), hlm. 103-106

23 Sutjihati Somantri, Psikologi Anak Luar Biasa, (Bandung: PT. Refika Aditama, 2006), hlm. 103-106

24 Mohammad, Effendi, Pengantar Psikopedagogik Anak Berkelainan, (Jakarta: Bumi Aksara, 2006), hlm. 90 


\section{2) Tunagrahita Sedang (imbecil)}

Tunagrahita sedang atau mampu latih adalah anak yang memiliki IQ 25-50, mereka hanya mampu dilatih untuk mengurus diri sendiri melalui aktivitas kehidupan sehari-hari.

3) Tunagrahita Berat (idiot)

Tunagrahita berat (idiot) atau mampu rawat memiliki IQ 0-25. mereka tidak mampu mengurus diri sendiri atau sosialisasi. Untuk mengurus kebutuhan diri sendiri sangat membutuhkan orang lain. Dengan kata lain, anak tunagrahita berat atau mampu rawat ini merupakan anak tunagrahita yang membutuhkan perawatan sepenuhnya sepanjang hidupnya, karena ia tidak mampu terus hidup tanpa bantuan orang lain.

\section{Hubungan Antara Peran Guru dan Motivasi Belajar Agama Bagi Anak Tunagrahita}

Anak tunagrahita pada setiap tahap perkembangannya selalu mengalami kendala sehingga seringkali tampak sikap atau perilaku anak tunagrahita berada di bawah usia kalendernya. Keterlambatan perkembangan tersebut disebabkan karena taraf kecerdasan sangat rendah. Dalam permasalahan pendidikan anak, kita tidak boleh membedakan antara anak yang normal perkembangan jasmani dan rohaninya, dengan anak yang mengalami kelemahan mental atau sering disebut tunagrahita.

Kesempatan yang menjadi manusia mulia sebagai orang yang bertakwa diberikan kepada semua manusia, baik kaya, miskin, cacat atau tidak, semuanya sama di hadapan Allah. Sebagai warga negara, anak-anak tunagrahita tidak didiskriminasikan untuk memperoleh pendidikan. Kelainan ini menjadi penting untuk diperhatikan dalam pemberian layanan pendidikan dan pengajaran anak tunagrahita adalah selain adanya motivasi dari orang tua juga adanya motivasi dari guru.

Motivasi belajar dari guru merupakan salah satu bentuk nyata pentingnya peran guru dalam pendidikan anak tunagrahita. Motivasi belajar pada anak tunagrahita merupakan salah satu bentuk penyesuaian diri terhadap lingkungan belajarnya, sehingga secara tidak langsung anak tunagrahita juga memiliki kemampuan menyesuaikan diri dengan lingkungan sosial yang lebih luas.

Motivasi belajar adalah merupakan faktor psikis yang bersifat intelektual, yang mempunyai peran menumbuhkan gairah merasa senang dan semangat untuk belajar pada siswa. Dengan demikian dapat dikatakan bahwa keberhasilan dalam belajar tidak semata ditentukan oleh intelegensi seseorang, tetapi ada faktor lain yaitu faktor non intelegensi yang di anaranya adalah faktor motivasi.

\section{Kesimpulan}

Dari uraian di atas, diambil kesimpulan bahwa guru mempunyai peranan penting dalam bidang pendidikan, salah satu peranan guru dalam kegiatan pembelajaran adalah sebagai motivator. Dalam hal ini guru harus mampu meningkatkan kegiatan atau merangsang dan memberikan dorongan kepada siswa agar mempunyai semangat dalam belajar agama, khususnya 
dalam proses kegiatan pembelajaran pada anak tunagrahita yang memiliki kondisi mental yang berbeda dari anak (siswa) normal. Oleh karena itu, sangatlah penting bagi guru untuk memberikan dorongan atau rangsangan agar mereka mempunyai semangat dan minat dalam belajar agama.

Ada beberapa upaya yang dapat dilakukan guru dalam meningkatkan motivasi belajar di antaranya adalah menggairahkan anak didik, memberikan harapan, memberikan insentif dan mengarahkan perilaku anak didik.

\section{Bibliografi}

Abdurrahman Mas'ud, M.A., Ph.D., 2007. Mengagas Format Pendidikan Nondikotomik, Yogyakarta : Gama Media.

Ahmad Tafsir, 2004, Ilmu Pendidikan Dalam Perspektif Islam, Bandung: Remaja Rosdakarya.

Dr. H. Abuddin Nata, M.A. 2001. Perspektif Islam tentang Pola Hubungan Guru-Murid, Jakarta: Raja Grafindo Persada.

http://mustanginbuchory89.blogspot.co.id/2015_05_01_archive.html yang diakses pada tanggal 15 Februari 2016, pukul. 10.30 WIB

https://tunagrahita.wordpress.com/author/tunagrahita/ yang diakses pada tanggal 20 Februari 2016, pukul 19.00 WIB

Moh. Uzer Usman, 1998, Menjadi Guru Profesional, Bandung: Remaja Rosdakarya.

Mohammad, Effendi, 2006, Pengantar Psikopedagogik Anak Berkelainan, Jakarta: Bumi Aksara.

Muhaimin, 2002, Paradigma Pendidikan Islam (Upaya Mengefektifkan Pendidikan Agama Islam di Sekolah), Bandung: Remaja Rosdakarya.

Nana Sudjana, 1987, Dasar-dasar Proses Belajar Mengajar, Bandung: Sinar Bumi.

Ngalim Purwanto, 1995, Psikologi Pendidikan, Bandung: Remaja Rosdakarya.

Sardiman A.M, 1996, Interaksi dan Motivasi Belajar Mengajar, Jakarta: Raja Grafindo Persada. , 2000, Interaksi dan Motivasi Belajar Mengajar, Jakarta: Raja Grafindo Persada 2001, Interaksi dan Motivasi Belajar Mengajar, Jakarta: Raja Grafindo Persada

Sitjihati Somantri, 2006, Psikologi Anak Luar Biasa, Bandung: Refika Aditama.

Syafrudin Nurdin, 2002, Guru Profesional dan Implementasi Kurikulum, Jakarta: Ciputat Press. 
76 | Etik Kurniawati

Syaiful Bahri Djamarah, 2000, Guru dan Anak Didik dalam Interaksi Edukatif, Jakarta: Rineka Cipta. , 2002, Psikologi Belajar, Jakarta: Rineka Cipta.

Winkel, 1987, Psikologi Pengajaran, Jakarta: Grasindo. 